\title{
RESEARCH OF CHANGING OF PASSENGER CAPACITY OF RIVER CRUISE PASSENGER VESSELS
}

\section{ИССЛЕДОВАНИЕ ИЗМЕНЕНИЯ ПАССАЖИРОВМЕСТИМОСТИ РЕЧНЫХ КРУИЗНЫХ ПАССАЖИРСКИХ СУДОВ}

\author{
Alexander G. Egorov \\ egorovag@meb.com.ua \\ ORCID 0000-0002-2050-8640
}

\author{
А. Г. Егоров, \\ канд. техн. наук, ст. науч. сотр.
}

Marine Engineering Bureau, Odesa

Морское Инженерное Бюро, г. Одесса

\begin{abstract}
Purpose. Determination of actual passenger capacity of river cruise passenger vessels in operation with forecast till 2030. Methodology. Methods of statistical processing, analysis, ship theory and design are applied. Results. Research of passenger capacity executed in work has shown that total passenger capacity of river cruise passenger vessels will decrease to 11631 persons (on 52.72\%) by 2030. Scientific novelty. New approach to classification of river cruise passenger vessels in connection with executed modernizations and conversion is offered. Practical impact. Total passenger capacity of native river cruise passenger vessels continues to decrease both due to write-off of vessels and due to reduction of number of places because of comfortableness increase during re-equipment. When developing projects of new vessels and modernization of existing ones it is extremely important to know real situation with actual passenger capacity. For the solution of problem 113 cruise passenger vessels with active class have been investigated. It has been found out that all vessels have been in varying degrees re-equipped or modernized. 43 cruise passenger vessels (38.7\% of all operating in navigation of 2019) were significantly modernized with increase of comfortableness level. Modernization and re-equipment works are still in progress. For significant modernization of vessels from the first group passenger capacity by average decreases on $52.3 \%$, for philosophy save modernization - on $32 \%$. For significant modernization of vessels from the second group passenger capacity by average decreases on $37 \%$, for philosophy save modernization - on $16.1 \%$. To save "river cruise" concept, and not only for foreign tourists, on mid-term and long-term perspectives building of new passenger vessels which fully satisfy market requests is recommended. Cruise passenger vessels for classical river routes (PV300, PV500VB, PV09, PKS-180, etc.) and river-sea vessels for operation both in adjacent seas and on river routes (PV300VD, PV11, etc.) are among these vessels.
\end{abstract}

Key words: river cruise; river cruise passenger vessel; passenger capacity; utilization; modernization; conversion; prognosis; analysis.

Анотація. Мета. Визначення фактичної пасажиромісткості працюючих річкових круїзних пасажирських суден із прогнозом до 2030 року. Методика. Застосовано методи статистичної обробки, аналізу, теорії корабля і проектування суден. Результати. Виконане в роботі дослідження пасажиромісткості показало, що загальна пасажиромісткість річкових круїзних пасажирських суден знизиться до 11631 чоловіка (на 52,72\%) до 2030 року. Наукова новизна. Запропоновано новий підхід до класифікації річкових круїзних пасажирських суден по факту виконаних модернізацій і конверсій. Практична значимість. Загальна пасажиромісткість вітчизняних річкових круїзних пасажирських суден продовжує знижуватися як за рахунок списання суден, так і за рахунок зменшення числа місць у разі підвищення комфортабельності під час переобладнань. Під час розробки проектів нових суден і модернізації існуючих надто важливо мати уявлення про реальну ситуацію з фактичною пасажиромісткістю. Для розв'язку поставленого завдання було досліджено 113 круїзних пасажирських суден, які мають діючий клас. Було виявлено, що всі судна тією чи іншою мірою були переобладнані або модернізовані. Суттєво модернізовані 3 підвищенням рівня комфортабельності 43 круїзних пасажирських судна (38,7\% від усіх працюючих у навігацію 2019 року). Роботи з модернізації та переобладнання тривають. За істотної модернізації суден із першої групи пасажиромісткість у середньому зменшується на 52,3\%, у разі збереження філософії - на 32\%; за істотної модернізації суден із другої групи - на 37\%, у разі збереження філософії - на 16,1\%. Для збереження поняття «річковий круїз», і не тільки для іноземних туристів, рекомендується на середньострокову й довгострокову перспективу будівництво нових пасажирських суден, які б найбільш повно задовольняли запитам ринку. Це можуть бути круїзні пасажирські судна як для класичних річкових маршрутів (PV300, PV500VB, PV09, ПКС-180 і т.п.), так i судна змішаного плавання для роботи в прибережних морях і на річкових маршрутах (PV300VD, PV11 i т.п.).

Ключові слова: річковий круїз; річкове круїзне пасажирське судно; пасажиромісткість; утилізація; модернізація; конверсія; прогноз; аналіз. 


\begin{abstract}
Аннотация. Цель. Определение фактической пассажировместимости работающих речных круизных пассажирских судов с прогнозом до 2030 года. Методика. Применены методы статистической обработки, анализа, теории корабля и проектирования судов. Результаты. Выполненное в работе исследование пассажировместимости показало, что общая пассажировместимость речных круизных пассажирских судов снизится до 11631 человека (на 52,72\%) к 2030 году, и это не считая возможного уменьшения пассажировместимости за счет будущих модернизационных работ. Научная новизна. Предложен новый подход к классификации речных круизных пассажирских судов по факту выполненных модернизаций и конверсий. Практическое значение. Для сохранения понятия «речной круиз», и не только для иностранных туристов, рекомендуется на среднесрочную и долгосрочную перспективу строительство новых пассажирских судов, которые бы наиболее полно удовлетворяли запросам рынка. Это могут быть круизные пассажирские суда как для классических речных маршрутов (PV300, PV500VB, PV09, ПКС-180 и т.п.), так и суда смешанного плавания для работы в прибрежных морях и на речных маршрутах (PV300VD, PV11 и т.п.).
\end{abstract}

Ключевые слова: речной круиз; речное круизное пассажирское судно; пассажировместимость; утилизация; модернизация; конверсия; прогноз; анализ.

\section{ПОСТАНОВКА ЗАДАЧИ}

Отечественный рынок речных круизных перевозок, несмотря на кризисные явления начала XXI века, продолжает развиваться: строятся новые речные круизные пассажирские суда (далее - РКПС), в том числе с использованием судов-доноров, переоборудуются и модернизируются старые, появляются новые взгляды на организацию круизов, новые маршруты.

Такое развитие - вполне адекватная реакция рынка на спрос со стороны клиентов (растет платежеспособность, повышаются требования к качеству круиза, увеличивается спрос у иностранных туристов на круизы не только на классических линиях Киев - Херсон - Одесса, Москва - Санкт-Петербург, но и, к примеру, на частично морские линии с выходом в Черное и Каспийское моря, на круизы по восточным рекам).

Но далеко не все существующие РКПС переоборудованы и модернизированы под современные понятия круизного судна, да и, как показало исследование $[1$, c. 50-57], не все проекты одинаково подходят для переоборудования, затраты могут достигать 30-50\% от стоимости нового судна, как следствие - утилизация определенной части РКПС.

Общая пассажировместимость отечественных РКПС при этом продолжает снижаться как за счет списания судов, так и за счет уменьшения числа мест при повышении комфортабельности во время переоборудований.

\section{АНАЛИЗ ПОСЛЕДНИХ ИССЛЕДОВАНИЙ \\ И ПУБЛИКАЦИЙ И ВЫДЕЛЕНИЕ НЕ РЕШЕННЫХ РАНЕЕ ЧАСТЕЙ ОБЩЕЙ ПРОБЛЕМЫ}

В литературе отсутствует детальная оценка фактической пассажировместимости существующих РКПС. Не опубликованы материалы по обоснованному прогнозу пассажировместимости на среднесрочную перспективу. В международном обзоре европейского речного рынка круизов приведены общие данные по количеству РКПС [2].
При разработке проектов новых РКПС и модернизации существующих крайне важно иметь представление о реальной ситуации с фактической пассажировместимостью РКПС, поэтому настоящее исследование представляется актуальным и своевременным.

Цель исследования - определение фактической пассажировместимости работающих РКПС с прогнозом до 2030 года.

\section{МЕТОДЫ, ОБЪЕКТ И ПРЕДМЕТ ИССЛЕДОВАНИЯ}

В работе применяются методы статистической обработки, анализа, теории корабля и проектирования судов. Объект исследования - пассажировместимость речных круизных пассажирских судов. Предмет исследования - характеристики речных круизных пассажирских судов, которые определяют пассажировместимость с учетом расположения и компоновки помещений.

\section{ОСНОВНОЙ МАТЕРИАЛ}

Для решения поставленной задачи были исследованы 113 РКПС, имеющих действующий класс РРР (на 2019 год) - см. таблицу 1.

В таблице 1 приведены также два круизных судна проекта 301 «Викинг Синеус» и «Принцесса Днепра», работающие на Днепре, круизное судно проекта 1168 «Белая Русь», выполняющее круизы в Беларуси, а также два судна проекта ПКС-40 и судно проекта 1877 «Россия», которые не совершают круизы.

Было выявлено, что все суда в той или иной степени были переоборудованы или модернизированы (см. таблицу 2).

При этом под понятием «сохранение философии» автор понимал такой тип модернизации, при которой сохранялся уровень комфортабельности.

В свою очередь «существенная модернизация», соответственно, была направлена на повышение уровня комфортабельности судна.

Существенно модернизированы с повышением уровня комфортабельности 43 круизных пассажир- 
Таблица 1. Данные по пассажировместимости речных круизных пассажирских судов, имеющих действующий класс РРР на 2019 год

\begin{tabular}{|c|c|c|c|c|c|c|c|}
\hline 里 & 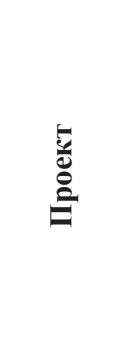 & 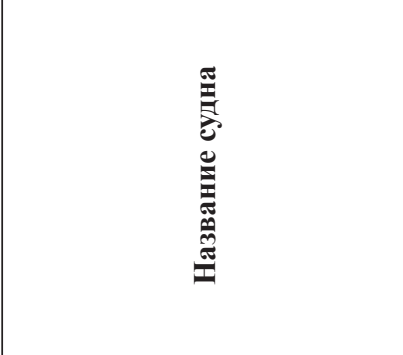 & 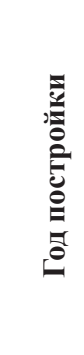 & \begin{tabular}{|l} 
\\
\end{tabular} & 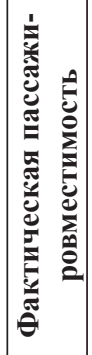 & 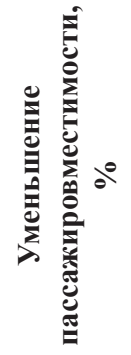 & 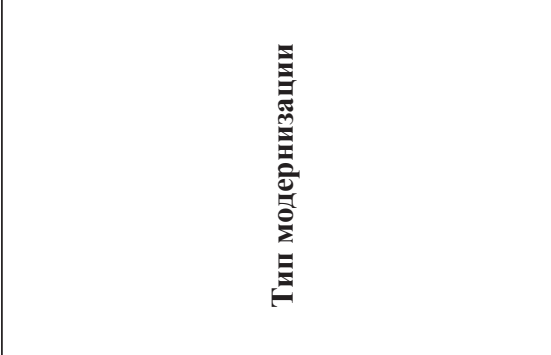 \\
\hline 1 & 2 & 3 & 4 & 5 & 6 & 7 & 8 \\
\hline 1 & 301 & Виссарион Белинский & 1980 & 360 & 289 & $19,72 \%$ & Сохранение философии \\
\hline 2 & 301 & Александр Радищев & 1982 & 360 & 272 & $24,44 \%$ & Сохранение философии \\
\hline 3 & 301 & Константин Коротков & 1976 & 360 & 255 & $29,17 \%$ & Сохранение философии \\
\hline 4 & 301 & Константин Федин & 1980 & 360 & 222 & $38,33 \%$ & Существенная модернизация \\
\hline 5 & 301 & Кронштадт & 1979 & 360 & 222 & $38,33 \%$ & Существенная модернизация \\
\hline 6 & 301 & Нижний Новгород & 1977 & 360 & 214 & $40,56 \%$ & Существенная модернизация \\
\hline 7 & 301 & Николай Чернышевский & 1981 & 360 & 228 & $36,67 \%$ & Существенная модернизация \\
\hline 8 & 301 & Санкт-Петербург & 1974 & 360 & 210 & $41,67 \%$ & Существенная модернизация \\
\hline 9 & 301 & Андрей Рублев & 1981 & 360 & 296 & $17,78 \%$ & Сохранение философии \\
\hline 10 & 301 & Княжна Виктория & 1982 & 360 & 206 & $42,78 \%$ & Балконы, существенная модернизация \\
\hline 11 & 301 & Михаил Булгаков & 1979 & 360 & 307 & $14,72 \%$ & Частично балконы, сохранение философии \\
\hline 12 & 301 & Николай Карамзин & 1981 & 360 & 309 & $14,17 \%$ & Сохранение философии \\
\hline 13 & 301 & Россия & 1978 & 360 & 224 & $37,78 \%$ & Балконы, существенная модернизация \\
\hline 14 & 301 & Петр Чайковский & 1977 & 360 & 207 & $42,50 \%$ & Существенная модернизация \\
\hline 15 & 301 & Тихий Дон & 1977 & 360 & 232 & $35,56 \%$ & Существенная модернизация \\
\hline 16 & 301 & Владимир Маяковский & 1978 & 360 & 317 & $11,94 \%$ & Сохранение философии \\
\hline 17 & 301 & Федор Достоевский & 1983 & 360 & 280 & $22,22 \%$ & Сохранение философии \\
\hline 18 & 301 & Викинг Рюрик & 1975 & 360 & 215 & $40,28 \%$ & Балконы, существенная модернизация \\
\hline 19 & $92-016$ & Феликс Дзержинский & 1978 & 400 & 339 & $15,25 \%$ & Сохранение философии \\
\hline 20 & $92-016$ & Сергей Кучкин & 1979 & 400 & 300 & $25,00 \%$ & Сохранение философии \\
\hline 21 & $92-016$ & Михаил Фрунзе & 1980 & 400 & 328 & $18,00 \%$ & Сохранение философии \\
\hline 22 & $92-016$ & Мстислав Ростропович & 1981 & 400 & 212 & $47,00 \%$ & Балконы, существенная модернизация \\
\hline 23 & $92-016$ & Александр Суворов & 1981 & 400 & 307 & $23,25 \%$ & Сохранение философии \\
\hline 24 & $92-016$ & Семён Будённый & 1981 & 400 & 299 & $25,25 \%$ & Сохранение философии \\
\hline 25 & $92-016$ & Георгий Жуков & 1983 & 400 & 318 & $20,50 \%$ & Сохранение философии \\
\hline 26 & 302 & Константин Симонов & 1984 & 332 & 288 & $13,25 \%$ & Сохранение философии \\
\hline 27 & 302 & Ленин & 1987 & 332 & 278 & $16,27 \%$ & Сохранение философии \\
\hline 28 & 302 & Георгий Чичерин & 1988 & 332 & 298 & $10,24 \%$ & Сохранение философии \\
\hline 29 & 302 & Зосима Шашков & 1986 & 332 & 298 & $10,24 \%$ & Сохранение философии \\
\hline 30 & 302 & Леонид Соболев & 1985 & 332 & 284 & $14,46 \%$ & Сохранение философии \\
\hline 31 & 302 & Русь & 1987 & 332 & 282 & $15,06 \%$ & Сохранение философии \\
\hline 32 & 302 & Юрий Андропов & 1986 & 332 & 296 & $10,84 \%$ & Сохранение философии \\
\hline 33 & 302 & Княжна Анастасия & 1989 & 332 & 298 & $10,24 \%$ & Сохранение философии \\
\hline 34 & 302 & Леонид Красин & 1989 & 332 & 317 & $4,52 \%$ & Сохранение философии \\
\hline 35 & $302 \mathrm{M}$ & $\begin{array}{l}\text { Максим Литвинов } \\
\text { (Кандинский) }\end{array}$ & 1991 & 350 & 200 & $42,86 \%$ & Существенная модернизация \\
\hline 36 & 302 & Генерал Лавриненков & 1990 & 332 & 184 & $44,58 \%$ & Балконы, существенная модернизация \\
\hline 37 & 302 & Иван Бунин & 1985 & 332 & 216 & $34,94 \%$ & Существенная модернизация \\
\hline 38 & 302 & Игорь Стравинский & 1985 & 332 & 220 & $33,73 \%$ & Балконы, существенная модернизация \\
\hline 39 & 302 & Сергей Дягилев (Рахманинов) & 1983 & 332 & 208 & $37,35 \%$ & Существенная модернизация \\
\hline 40 & 302 & Волга Стар & 1984 & 332 & 200 & $39,76 \%$ & Существенная модернизация \\
\hline 41 & 302 & Дмитрий Фурманов & 1983 & 332 & 250 & $24,70 \%$ & Частично балконы, сохранение философии \\
\hline 42 & 302 & Лебединое Озеро & 1986 & 332 & 250 & $24,70 \%$ & $\begin{array}{l}\text { Частично балконы, сохранение } \\
\text { философии }\end{array}$ \\
\hline
\end{tabular}


Продовження таблиці 1

\begin{tabular}{|c|c|c|c|c|c|c|c|}
\hline 1 & 2 & 3 & 4 & 5 & 6 & 7 & 8 \\
\hline 43 & 302 & Лунная соната & 1988 & 332 & 290 & $12,65 \%$ & $\begin{array}{l}\text { Частично балконы, сохранение } \\
\text { философии }\end{array}$ \\
\hline 44 & 302 & Викинг Ингвар & 1990 & 332 & 250 & $24,70 \%$ & Балконы, существенная модернизация \\
\hline 45 & 302 & Викинг Хельги & 1984 & 332 & 250 & $24,70 \%$ & Балконы, существенная модернизация \\
\hline 46 & 302 & Викинг Акун & 1988 & 332 & 250 & $24,70 \%$ & Балконы, существенная модернизация \\
\hline 47 & 302 & Викинг Трувор & 1987 & 332 & 250 & $24,70 \%$ & Балконы, существенная модернизация \\
\hline 48 & $302 \mathrm{M}$ & А.С. Пушкин & 1990 & 350 & 344 & $1,71 \%$ & Сохранение философии \\
\hline 49 & Q-040 & Александр Пушкин & 1974 & 216 & 186 & $13,89 \%$ & Сохранение философии \\
\hline 50 & Q-040 & Максим Горький & 1974 & 216 & 186 & $13,89 \%$ & $\begin{array}{l}\text { Сохранение философии, в } 2019 \text { г. } \\
\text { не работает, с } 2020 \text { г. - перевод на Енисей }\end{array}$ \\
\hline 51 & Q-040 & Василий Суриков & 1975 & 216 & 190 & $12,04 \%$ & Сохранение философии \\
\hline 52 & Q-040 & Илья Репин & 1975 & 216 & 186 & $13,89 \%$ & $\begin{array}{l}\text { Частично балконы, сохранение } \\
\text { философии }\end{array}$ \\
\hline 53 & Q-056 & Антон Чехов & 1978 & 250 & 182 & $27,20 \%$ & Сохранение философии \\
\hline 54 & Q-056 & Лев Толстой & 1979 & 250 & 178 & $28,80 \%$ & $\begin{array}{l}\text { Сохранение философии, в } 2019 \text { г. } \\
\text { не работает }\end{array}$ \\
\hline 55 & Q-065 & Сергей Есенин & 1984 & 180 & 136 & $24,44 \%$ & $\begin{array}{l}\text { Частично балконы, существенная } \\
\text { модернизация }\end{array}$ \\
\hline 56 & Q-065 & Демьян Бедный & 1986 & 180 & 210 & $-16,67 \%$ & Сохранение философии, Лена \\
\hline 57 & Q-065 & Михаил Светлов & 1985 & 180 & 210 & $-16,67 \%$ & Сохранение философии, Лена \\
\hline 58 & 463 & Принцесса Анабелла & 1973 & 124 & 98 & $20,97 \%$ & Сохранение философии \\
\hline 59 & PV08 & Александр Грин & 2012 & 180 & 112 & $37,78 \%$ & $\begin{array}{l}\text { Балконы, конверсия, существенная } \\
\text { модернизация }\end{array}$ \\
\hline 60 & \begin{tabular}{|c|}
$588 /$ \\
РЕГК.002 \\
\end{tabular} & Русь Великая & 2013 & 339 & 196 & $42,18 \%$ & Конверсия, сохранение философии \\
\hline 61 & $26-37$ & Афанасий Никитин & 1959 & 312 & 255 & $18,27 \%$ & Сохранение философии \\
\hline 62 & $26-37$ & Иван Кулибин & 1960 & 312 & 259 & $16,99 \%$ & Сохранение философии \\
\hline 63 & $26-37$ & Октябрьская Революция & 1957 & 312 & 255 & $18,27 \%$ & Сохранение философии \\
\hline 64 & $26-37$ & Родная Русь & 1961 & 312 & 235 & $24,68 \%$ & Сохранение философии \\
\hline 65 & $26-37$ & Н.А. Некрасов & 1961 & 312 & 146 & $53,21 \%$ & Существенная модернизация \\
\hline 66 & $26-37$ & Александр Бенуа & 1960 & 312 & 144 & $53,85 \%$ & Существенная модернизация \\
\hline 67 & $26-37$ & Валерий Чкалов & 1961 & 312 & 196 & $37,18 \%$ & Сохранение философии \\
\hline 68 & $26-37$ & Волга Дрим & 1959 & 312 & 109 & $65,06 \%$ & Существенная модернизация \\
\hline 69 & $\begin{array}{c}26-37 / 92- \\
055 \\
\end{array}$ & Капитан Пушкарев & 1960 & 312 & 210 & $32,69 \%$ & Сохранение философии \\
\hline 70 & $26-37$ & Михаил Танич & 1962 & 312 & 226 & $27,56 \%$ & Сохранение философии \\
\hline 71 & $26-37$ & Президент & 1961 & 312 & 146 & $53,21 \%$ & Существенная модернизация \\
\hline 72 & 305 & Алдан & 1960 & 311 & 148 & $52,41 \%$ & Сохранение философии \\
\hline 73 & 305 & Александр Свешников & 1961 & 311 & 149 & $52,09 \%$ & Сохранение философии \\
\hline 74 & 305 & Александр Свирский & 1963 & 311 & 184 & $40,84 \%$ & Сохранение философии \\
\hline 75 & 305 & Сергей Образцов & 1961 & 311 & 159 & $48,87 \%$ & Существенная модернизация \\
\hline 76 & 305 & Павел Миронов & 1962 & 311 & 215 & $30,87 \%$ & $\begin{array}{l}\text { Сохранение философии, в } 2019 \text { г. } \\
\text { не работает }\end{array}$ \\
\hline 77 & 305 & Борис Полевой & 1961 & 311 & 140 & $54,98 \%$ & Сохранение философии \\
\hline 78 & 305 & Бородино & 1961 & 311 & 161 & $48,23 \%$ & Сохранение философии \\
\hline 79 & 305 & Василий Чапаев & 1964 & 311 & 166 & $46,62 \%$ & Существенная модернизация \\
\hline 80 & 305 & Ремикс & 1964 & 311 & 53 & $82,96 \%$ & Существенная модернизация, Обь-Иртыш \\
\hline 81 & 305 & Григорий Пирогов & 1961 & 311 & 179 & $42,44 \%$ & Сохранение философии \\
\hline 82 & 305 & Башкортостан & 1962 & 311 & 132 & $57,56 \%$ & Сохранение философии \\
\hline 83 & 588 & И.А. Крылов & 1956 & 364 & 210 & $42,31 \%$ & Существенная модернизация \\
\hline 84 & 588 & А. Матросов & 1954 & 364 & 250 & $31,32 \%$ & Сохранение философии, Енисей \\
\hline 85 & 588 & В. Чкалов & 1954 & 364 & 250 & $31,32 \%$ & Сохранение философии, Енисей \\
\hline 86 & 588 & Алексей Толстой & 1954 & 364 & 176 & $51,65 \%$ & Существенная модернизация \\
\hline 87 & 588 & Солнечный город & 1956 & 364 & 200 & $45,05 \%$ & Существенная модернизация \\
\hline
\end{tabular}


Закончення таблиці 1

\begin{tabular}{|c|c|c|c|c|c|c|c|}
\hline 1 & 2 & 3 & 4 & 5 & 6 & 7 & 8 \\
\hline 88 & 588 & Цезарь & 1955 & 364 & 150 & $58,79 \%$ & Существенная модернизация \\
\hline 89 & 588 & Очарованный Странник & 1956 & 364 & 220 & $39,56 \%$ & Сохранение философии \\
\hline 90 & 588 & Дмитрий Пожарский & 1957 & 339 & 245 & $27,73 \%$ & Сохранение философии \\
\hline 91 & 588 & А.С. Попов & 1961 & 339 & 167 & $50,74 \%$ & Балконы, существенная модернизация \\
\hline 92 & 588 & А.И. Герцен & 1959 & 339 & 251 & $25,96 \%$ & Сохранение философии \\
\hline 93 & 588 & Космонавт Гагарин & 1958 & 339 & 187 & $44,84 \%$ & Сохранение философии \\
\hline 94 & 588 & Александр Фадеев & 1961 & 339 & 238 & $29,79 \%$ & Сохранение философии \\
\hline 95 & 588 & Ф.И. Панферов & 1961 & 339 & 150 & $55,75 \%$ & $\begin{array}{l}\text { Частично балконы, существенная } \\
\text { модернизация }\end{array}$ \\
\hline 96 & 588 & Хирург Разумовский & 1961 & 339 & 160 & $52,80 \%$ & $\begin{array}{l}\text { Частично балконы, существенная } \\
\text { модернизация }\end{array}$ \\
\hline 97 & 588 & Александр Невский & 1957 & 339 & 196 & $42,18 \%$ & Существенная модернизация \\
\hline 98 & 588 & Две столицы & 1961 & 339 & 212 & $37,46 \%$ & Существенная модернизация \\
\hline 99 & 588 & Илья Муромец & 1958 & 339 & 152 & $55,16 \%$ & Существенная модернизация \\
\hline 100 & 588 & К.А. Тимирязев & 1959 & 339 & 240 & $29,20 \%$ & Сохранение философии \\
\hline 101 & 588 & Козьма Минин & 1960 & 339 & 265 & $21,83 \%$ & Сохранение философии \\
\hline 102 & 588 & Михаил Кутузов & 1957 & 339 & 234 & $30,97 \%$ & Сохранение философии \\
\hline 103 & 588 & Н.В. Гоголь & 1959 & 339 & 220 & $35,10 \%$ & $\begin{array}{l}\text { Частично балконы, существенная } \\
\text { модернизация }\end{array}$ \\
\hline 104 & 588 & Павел Бажов & 1960 & 339 & 232 & $31,56 \%$ & Сохранение философии \\
\hline 105 & 588 & Урал & 1958 & 339 & 296 & $12,68 \%$ & Сохранение философии \\
\hline 106 & 588 & Северная сказка & 1957 & 339 & 153 & $54,87 \%$ & Существенная модернизация \\
\hline 107 & 646 & Господин Великий Новгород & 1954 & 197 & 120 & $39,09 \%$ & Сохранение философии \\
\hline 108 & 646 & Механик Калашников & 1955 & 197 & 145 & $26,40 \%$ & Сохранение философии, Обь-Иртыш \\
\hline 109 & 646 & Родина & 1955 & 197 & 276 & $-40,10 \%$ & $\begin{array}{l}\text { Сохранение философии, } \\
\text { линейные перевозки, Обь-Иртыш }\end{array}$ \\
\hline 110 & 646 & Механик Кулибин & 1955 & 197 & 169 & $14,21 \%$ & Сохранение философии, Лена \\
\hline 111 & 646 & Близняк & 1954 & 197 & 56 & $71,57 \%$ & Существенная модернизация, Енисей \\
\hline 112 & PV09 & Штандарт & 2017 & & 36 & & Новострой \\
\hline 113 & ПКС-40 & Cypa & 2011 & & 200 & & Новострой \\
\hline$*$ & ПКС-40 & Колёсовъ & 2014 & & 200 & & Новострой, используется как прогулочное \\
\hline$*$ & ПКС-40 & Доброходъ & 2015 & & 200 & & Новострой, используется как прогулочное \\
\hline$*$ & 1877 & Россия & 1973 & & 45 & & Используется как служебно-разъездное \\
\hline$*$ & 1168 & Белая Русь & 2016 & & 30 & & Конверсия из проекта 354У, Беларусь \\
\hline$*$ & 301 & Принцесса Днепра & 1976 & 360 & 240 & $33,33 \%$ & Существенная модернизация, Украина \\
\hline$*$ & 301 & Викинг Синеус & 1979 & 360 & 196 & $45,56 \%$ & $\begin{array}{l}\text { Балконы, существенная модернизация, } \\
\text { Украина }\end{array}$ \\
\hline
\end{tabular}

Таблица 2. Данные по модернизациям активных речных круизных пассажирских судов на навигацию 2019 года

\begin{tabular}{|c|c|c|c|c|c|c|c|}
\hline \multirow[b]{2}{*}{ Проект } & \multicolumn{2}{|c|}{ Сохранение философии } & \multicolumn{3}{|c|}{ Существенная модернизация } & \multirow[b]{2}{*}{$\begin{array}{c}\text { Модернизация } \\
\text { в 2008-2013 }\end{array}$} & \multirow[b]{2}{*}{$\begin{array}{c}\text { Модернизация } \\
\text { в 2014-2019 }\end{array}$} \\
\hline & $\begin{array}{c}\text { Без } \\
\text { балконов } \\
\end{array}$ & $\begin{array}{l}\text { Частично } \\
\text { балконы } \\
\end{array}$ & $\begin{array}{c}\text { Без } \\
\text { балконов } \\
\end{array}$ & $\begin{array}{l}\text { Частично } \\
\text { балконы } \\
\end{array}$ & Балконы & & \\
\hline 301 & 7 & 1 & 7 & 0 & 3 & 3 & 8 \\
\hline $92-016$ & 6 & 0 & 0 & 0 & 1 & 1 & 0 \\
\hline 302 & 10 & 3 & 4 & 0 & 6 & 6 & 8 \\
\hline Q-040 & 3 & 1 & 0 & 0 & 0 & 0 & 2 \\
\hline Q-056 & 2 & 0 & 0 & 0 & 0 & 0 & 1 \\
\hline Q-065 & 2 & 0 & 0 & 1 & 0 & 0 & 1 \\
\hline 463 & 1 & 0 & 0 & 0 & 0 & 0 & 0 \\
\hline $\begin{array}{c}\text { 588/РЕГК } \\
\text { (конверсия) }\end{array}$ & 1 & 0 & 0 & 0 & 0 & 1 & 0 \\
\hline $\begin{array}{c}\text { PV08 } \\
\text { (конверсия) }\end{array}$ & 0 & 0 & 0 & 0 & 1 & 1 & 0 \\
\hline $26-37$ & 7 & 0 & 4 & 0 & 0 & 3 & 1 \\
\hline 305 & 8 & 0 & 3 & 0 & 0 & 1 & 3 \\
\hline 588 & 12 & 0 & 8 & 3 & 1 & 3 & 7 \\
\hline 646 & 4 & 0 & 1 & 0 & 0 & 0 & 1 \\
\hline PV09 & - & - & - & - & - & - & - \\
\hline ПКС-40 & - & - & - & - & - & - & - \\
\hline 301 (Днепр) & 0 & 0 & 1 & 0 & 1 & 0 & 2 \\
\hline Суммарно & 63 & 5 & 28 & 4 & 13 & 19 & 34 \\
\hline \multirow{2}{*}{$\begin{array}{c}\text { Суммарно без } \\
\text { Днепра }\end{array}$} & 63 & 5 & 27 & 4 & 12 & \multirow{2}{*}{19} & \multirow{2}{*}{32} \\
\hline & & & & 43 & & & \\
\hline
\end{tabular}




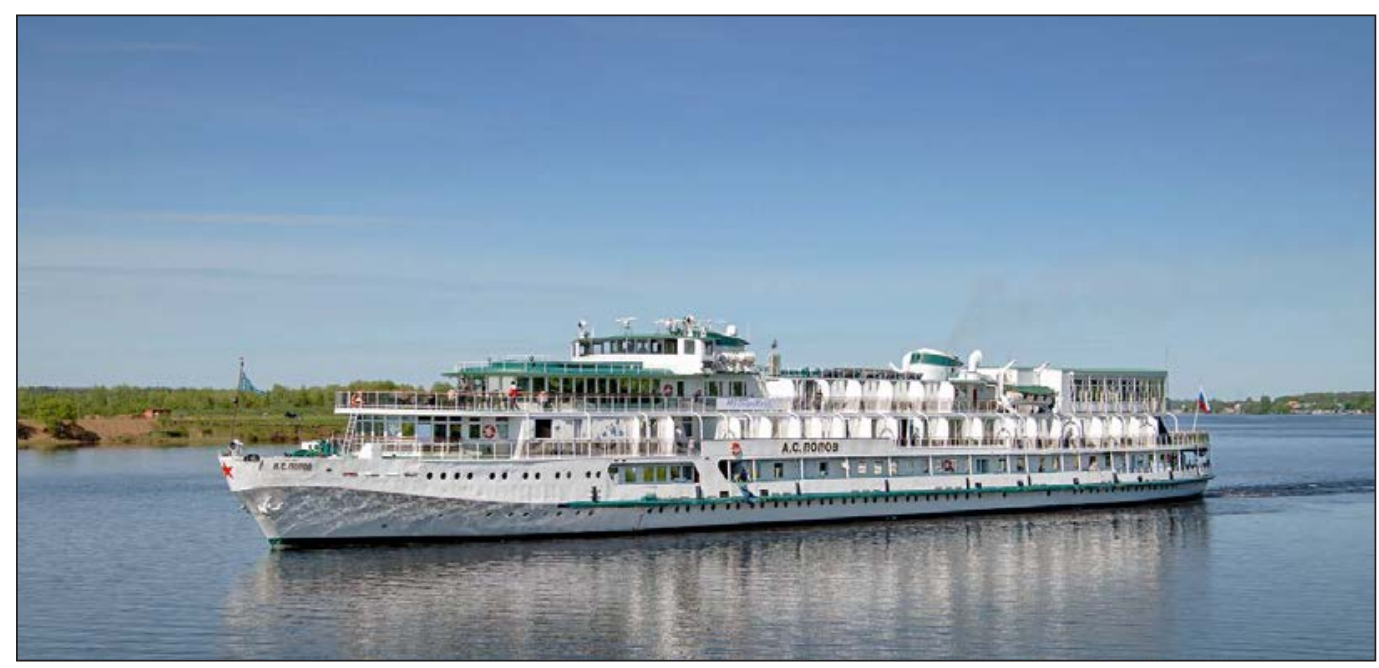

Рис. 1. Общий вид т/х «А.С. Попов» после модернизации 2018-2019 года. Автор фотографии Александр Конов [4]

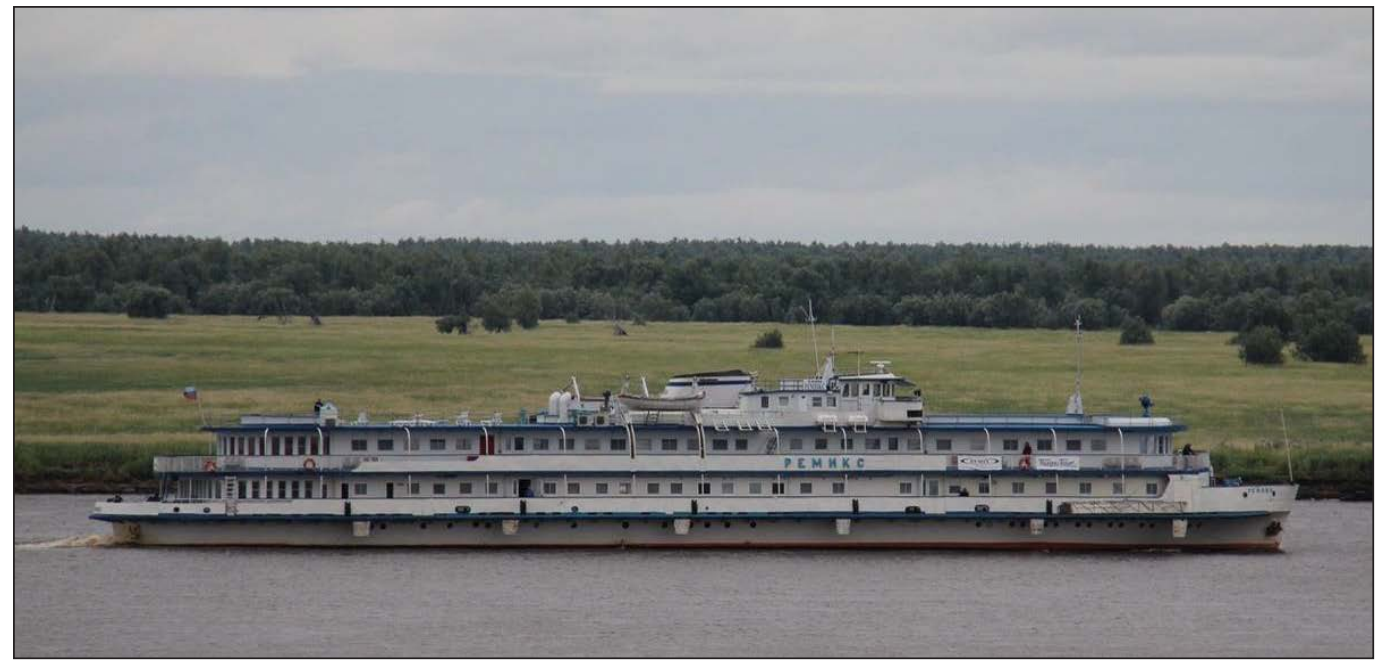

Рис. 2. Общий вид т/х «Ремикс» после модернизации 2018-2019 года. Автор фотографии Алексей Потелещенко [4]

ских судна (38,7\% от всех работающих в навигацию 2019 года).

При этом на 12-ти круизных пассажирских судах (10,8\% от всех работающих) были установлены балконы на всех палубах, на 9-ти судах - балконы установлены частично (для определенной категории номеров, чаще всего - для кают класса «Люкс»).

Работы по модернизации и переоборудованию продолжаются. За последние пять лет было модернизировано 34 судна (32 в России плюс два днепровских судна проекта 301).

Например, на рынок вышла швейцарская компания Thurgau Travel [3], для которой в межнавигационный период 2018-2019 годов были модернизированы сразу 2 РКПС, в том числе теплоход «А.С. Попов» («Thurgau Karelia») - первое судно проекта 588 с балконами не только для кают класса «Люкс».
На обновленном судне 71 каюта площадью 14-16 м² и 10 кают площадью 11-14 м², при этом количество пассажиров сократилось до 162 с 339 человек (на $52,2 \%$ ).

По внутренней классификации оператора судно категории $3+*$ (см. рисунок 1$)$.

Второй - теплоход «Ремикс» («Remix») - судно проекта 305 для работы на линии Салехард - Новосибирск (река Обь). На обновленном судне каюты площадью от 10 до $60 \mathrm{~m}^{2}$, количество пассажиров сократилось до 53 с 311 человек (на 83\%). По внутренней классификации оператора судно категории $3 *$ (см. рисунок 2).

Помимо компании Thurgau Travel в межнавигационный период 2018-2019 года активно работали над повышением комфортабельности компании «ВодоходЂ» (т/х «Нижний Новгород» и т/x «Санкт-Петербург»см. рисунок 3), «Мостурфлот» (т/х «Сергей Есенин», 


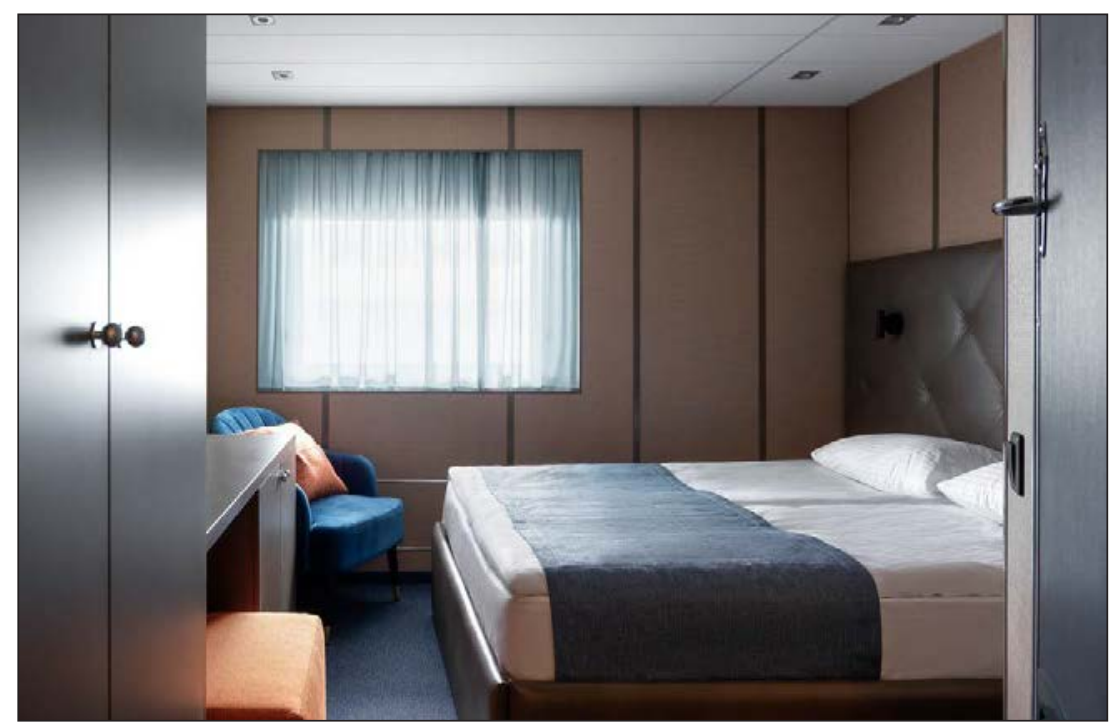

Рис. 3. Каюта «Делюкс» на обновленном т/х «Санкт-Петербург» [5]

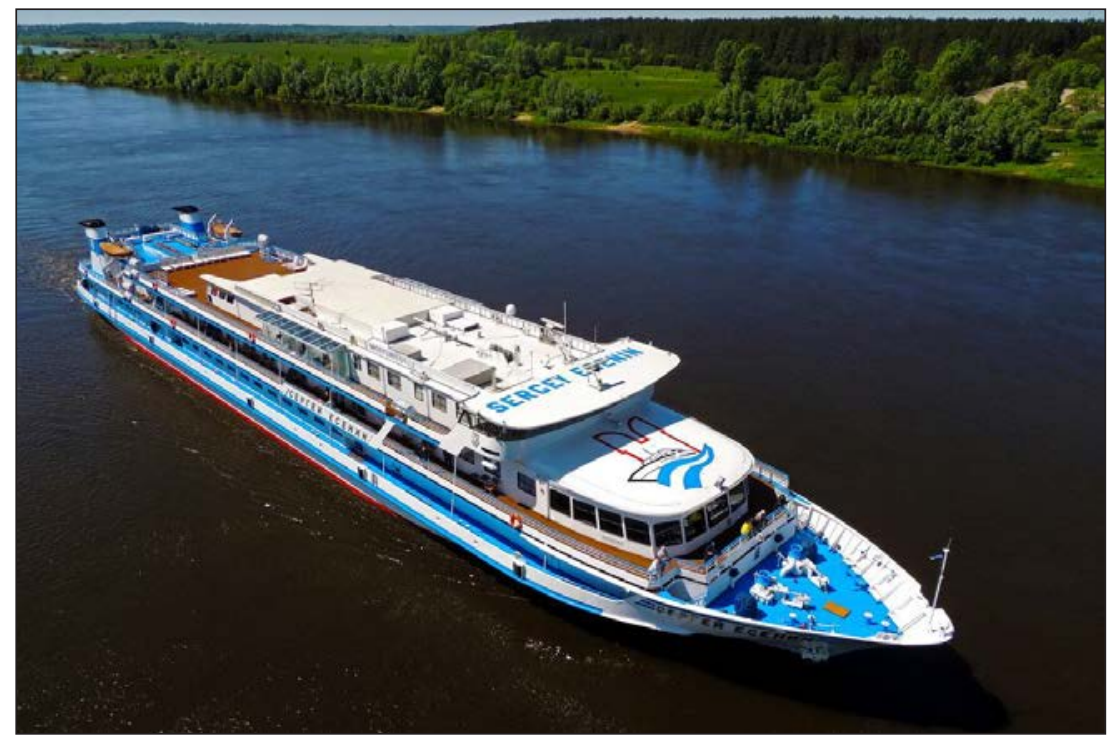

Рис. 4. Общий вид т/х «Сергей Есенин» после модернизации 2018-2019 года. Автор фотографии Максим Назаркин [4]

т/х «А.С. Пушкин», т/х «Россия» - см. рисунок 4), «Инфофлот» (т/x «Василий Чапаев», т/x «Северная сказка»), «Донинтурфлот» (т/х «Игорь Стравинский») и «Белый лебедь» (т/x «Бородино», т/x «К.А. Тимирязев»).

Автором была выполнена также средняя оценка влияния модернизации на пассажировместимость речных круизных пассажирских судов.

Для этого все активные РКПС были сгруппированы в две группы.

Первая (суда проектов 26-37, 588, 305, 646) - это грузопассажирские и пассажирские суда для дальних линий, построенные с начала 50-х до середины 60-х годов прошлого столетия.
Вторая группа судов (проекты 301, 302, Q-040, Q-056, Q-065, 92-016) - это суда, которые строились в 70-90-е годы, причем многие уже с учетом круизной функции [1, с. 55-57].

При существенной модернизации РКПС из первой группы пассажировместимость в среднем уменьшается на $52,3 \%$, при сохранении философии - на $32 \%$.

При существенной модернизации РКПС из второй группы - на 37\%, при сохранении философии - на 16,1\%.

В таблице 3 рассчитана общая пассажировместимость работающих в 2019 году речных круизных пассажирских судов, определен средний возраст работающих судов, а также, используя данные 


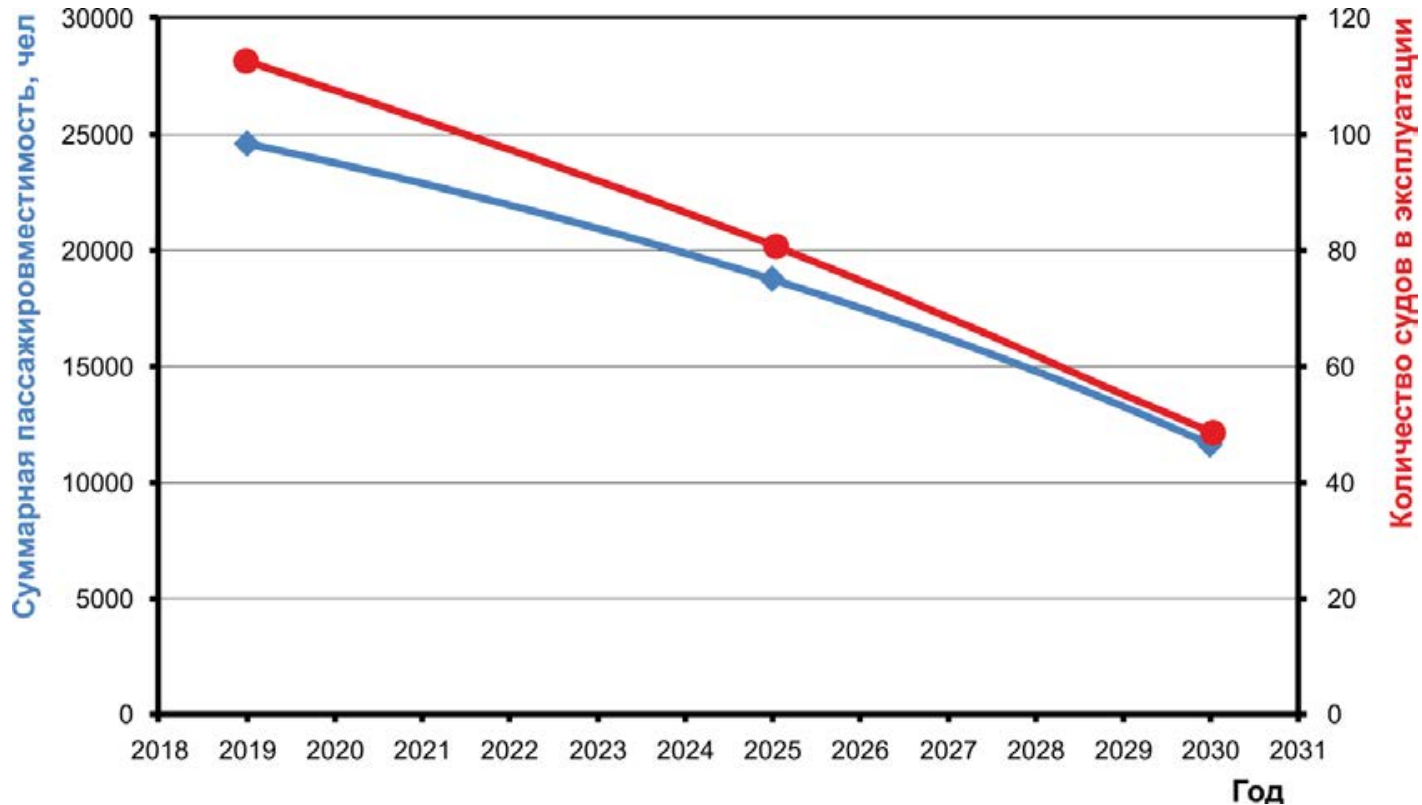

Рис. 5. Прогноз по общей пассажировместимости активных РКПС

Таблица 3. Общая пассажировместимость речных круизных пассажирских судов и прогноз до 2030 года

\begin{tabular}{|c|c|c|c|c|c|c|c|c|c|}
\hline \multirow[b]{2}{*}{ Проект } & \multicolumn{5}{|c|}{ Фактические данные на навигацию 2019 года } & \multicolumn{2}{|c|}{$\begin{array}{c}\text { Прогноз } \\
\text { на } 2025 \text { год }\end{array}$} & \multicolumn{2}{|c|}{$\begin{array}{c}\text { Прогноз } \\
\text { на } 2030 \text { год } \\
\end{array}$} \\
\hline & 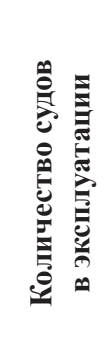 & 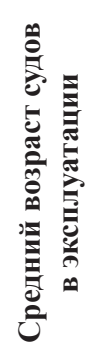 & 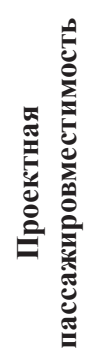 & 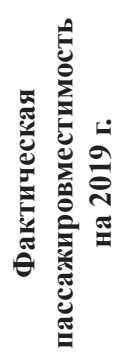 & 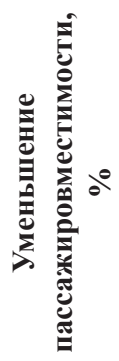 & 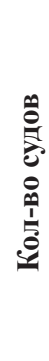 & 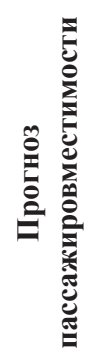 & 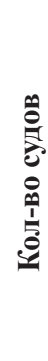 & 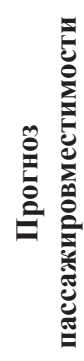 \\
\hline 301 & 18 & 40,11 & 6480 & 4505 & $30,48 \%$ & 16 & 4004 & 10 & 2503 \\
\hline 92-016 & 7 & 38,57 & 2800 & 2103 & $24,89 \%$ & 5 & 1502 & 2 & 601 \\
\hline 302 & 23 & 32,26 & 7672 & 6001 & $21,78 \%$ & 22 & 5740 & 18 & 4696 \\
\hline Q-040 & 4 & 44,50 & 864 & 748 & $13,43 \%$ & 2 & 374 & 1 & 187 \\
\hline Q-056 & 2 & 40,50 & 500 & 360 & $28,00 \%$ & 2 & 360 & 2 & 360 \\
\hline Q-065 & 3 & 34,00 & 540 & 556 & $-2,96 \%$ & 3 & 556 & 3 & 556 \\
\hline 463 & 1 & 46,00 & 124 & 98 & $20,97 \%$ & 0 & 0 & 0 & 0 \\
\hline 588/РЕГК.002 & 1 & 6,00 & 339 & 196 & $42,18 \%$ & 1 & 196 & 1 & 196 \\
\hline PV08 & 1 & 7,00 & 180 & 112 & $37,78 \%$ & 1 & 112 & 1 & 112 \\
\hline $26-37$ & 11 & 58,91 & 3432 & 2181 & $36,45 \%$ & 6 & 1190 & 1 & 198 \\
\hline 305 & 11 & 57,18 & 3421 & 1686 & $50,72 \%$ & 2 & 307 & 0 & 0 \\
\hline 588 & 24 & 61,13 & 8311 & 5054 & $39,19 \%$ & 12 & 2527 & 3 & 632 \\
\hline 646 & 5 & 64,40 & 985 & 766 & $22,23 \%$ & 2 & 306 & 0 & 0 \\
\hline \begin{tabular}{|l|} 
PV09 \\
\end{tabular} & 1 & 2,00 & 36 & 36 & & 1 & 36 & 1 & 36 \\
\hline ПКС-40 & 1 & 8,00 & 200 & 200 & & 1 & 200 & 1 & 200 \\
\hline 301 (Днепр) & 2 & 41,50 & 720 & 436 & $39,44 \%$ & 2 & 436 & 2 & 436 \\
\hline PV300 & & & & & & 2 & 684 & 2 & 684 \\
\hline PV300VD & & & & & & 1 & 310 & 1 & 310 \\
\hline ПКС-180 & & & & & & 2 & 360 & 2 & 360 \\
\hline Суммарно без Днепра & 113 & 46,28 & 35884 & 24602 & $31,44 \%$ & 81 & 18764 & 49 & 11631 \\
\hline
\end{tabular}




\section{СУДНОБУДУВАННЯ № 1 2019}

исследований авторов [1, с. 61], даны прогнозы по пассажировместимости на среднесрочную перспективу до 2030 года (см. рисунок 5).

Общая пассажировместимость на 2019 год составляет 24602 человека.

К 2030 году прогнозируется уменьшение пассажировместимости на 52,72\% до 11631 человека, и это не считая возможного уменьшения пассажировместимости за счет глубокой модернизации существующих круизных судов для повышения уровня комфортабельности в 2019-2030 годы.

При этом также не учитываются возможные новые РКПС, которые будут заказаны и построены (либо переоборудованы из других типов судов), начиная с 2020 года.

\section{ОБСУЖДЕНИЕ ПОЛУЧЕННЫХ РЕЗУЛЬТАТОВ И ВЫВОДЫ}

Выполненное в работе исследование показало, что общая пассажировместимость РКПС снизится до 11631 человека (на 52,72\%) к 2030 году, и это не считая возможного уменьшения пассажировместимости за счет будущих модернизационных работ.

Для сохранения понятия «речной круиз», и не только для иностранных туристов, рекомендуется на среднесрочную и долгосрочную перспективу строительство новых пассажирских судов, которые бы наиболее полно удовлетворяли запросам рынка. Это могут быть круизные пассажирские суда как для классических речных маршрутов (PV300, PV500VB, PV09, ПКС-180 и т.п.), так и суда смешанного плавания для работы в прибрежных морях и на речных маршрутах (PV300VD, PV11 и т.п.).

\section{REFERENCES}

[1] Egorov A.G. (2018). Issledovanie sostava flota rechnikh kruiznikh passazhirskikh sudov [Research of river cruise passenger vessels fleet composition]. Sudostroenie i morskaya infrastructura (Shipbuilding and Marine Infrastructure), 2 (10), 48-62 [in Russian].

[2] Cruise Industry News (2019). 2020 European River Cruise Market. Special report. Edited by Oivind Mathisen. - New York, $114 \mathrm{p}$.

[3] «Thurgau Travel» cruise company website. Retrieved from: https://www.thurgautravel.ch/ (access date 16.10.2019).

[4] «Fleet photo» website. Retrieved from: https://fleetphoto.ru/ (access date 16.10.2019).

[5] «Vodohod» cruise company website. Retrieved from: https://vodohod.com/ (access date 16.10.2019).

\section{СПИСОК ИСПОЛЬЗОВАННОЙ ЛИТЕРАТУРЫ}

[1] Егоров А. Г. (2018) Исследование состава флота речных круизных пассажирских судов. Судостроение и морская инфраструктура (Shipbuilding and Marine Infrastructure). № 2 (10). C. 48-62.

[2] Cruise Industry News (2019) 2020 European River Cruise Market. Special report. Edited by Oivind Mathisen. New York, $114 \mathrm{p}$.

[3] Сайт круизной компании «Thurgau Travel». URL: https://www.thurgautravel.ch/ (дата обращения: 16.10.2019).

[4] Сайт «Водный транспорт». URL: https://fleetphoto.ru/ (дата обращения: 16.10.2019).

[5] Сайт круизной компании «Водоходъ». URL: https://vodohod.com/ (дата обращения: 16.10.2019). 